\title{
The effect of carbon dioxide availability on succinic acid production with biofilms of Actinobacillus succinogenes
}

\author{
Jolandi Herselman ${ }^{\mathrm{a}}$, Michael F.A. Bradfield ${ }^{\mathrm{a}}, \mathrm{Uma} \mathrm{Vijayan}^{\mathrm{a}} \&$ Willie Nicol${ }^{\mathrm{a} *}$
}

${ }^{\mathrm{a}}$ Department of Chemical Engineering, University of Pretoria, Lynnwood Road, Hatfield, 0002, Pretoria, South Africa

Postal address: Department of Chemical Engineering, University of Pretoria, Private Bag X20, Hatfield, 0028, South Africa

Contact details:

Prof. Willie Nicol (corresponding author)*

willie.nicol@up.ac.za | Tel.: +27 124203796 | Fax: +27 124205048

Ms. Jolandi Herselman

herselman.jolandi@gmail.com

Mr. Michael Bradfield

michael.bradfield@tuks.co.za

Ms Uma Vijayan

u10065424@tuks.co.za 


\section{Highlights}

- Succinic acid productivity starts to decrease with decreasing dissolved $\mathrm{CO}_{2}$ below an upper threshold

- The decrease in productivity occurs at a constant flux distribution up to a lower $\mathrm{CO}_{2}$ threshold

- Below the lower threshold, succinic acid yields decrease as flux shifts to $\mathrm{C}_{3}$ pathways

- Ethanol formation increases with decreasing dissolved $\mathrm{CO}_{2}$ below the lower threshold 


\begin{abstract}
Carbon dioxide serves as a co-substrate in succinic acid (SA) production by Actinobacillus succinogenes making it an important consideration in fermentation optimisation. In the current study, the availability of $\mathrm{CO}_{2}$ to the cell, as the dissolved $\mathrm{CO}_{2}$ concentration in the fermentation broth $\left(\mathrm{C}_{\mathrm{CO}_{2}}\right)$, is shown to define three distinct steady-state regimes. At $\mathrm{C}_{\mathrm{CO}_{2}}$ values between $8.4 \mathrm{mM}( \pm 36.8 \%$ saturation $)$ and saturation $(22.8 \mathrm{mM})$, there is no evidence of $\mathrm{CO}_{2}$ limiting SA productivity and flux to $\mathrm{SA}$ is constant. As $\mathrm{C}_{\mathrm{CO}_{2}}$ is decreased, an upper $\mathrm{C}_{\mathrm{CO}_{2}}$ threshold $( \pm 36.8 \%$ saturation; $8.4 \mathrm{mM})$ is reached where metabolic flux distributions remain constant but SA productivity and substrate uptake start to decline with decreasing $\mathrm{C}_{\mathrm{CO}_{2}}$ levels. A further decrease in $\mathrm{C}_{\mathrm{CO}_{2}}$ leads to a lower $\mathrm{C}_{\mathrm{CO}_{2}}$ threshold $( \pm 17.1 \%$ saturation, $3.9 \mathrm{mM}$ ) where SA productivity continues to decrease with a concomitant shift in carbon flux away from $\mathrm{SA}$ towards $\mathrm{C}_{3}$ fermentative pathways including ethanol. Since SA production is not limited at relatively low $\mathrm{C}_{\mathrm{CO}_{2}}$ values ( $\pm 36.8 \%$ saturation), adequate $\mathrm{CO}_{2}$ supply to the fermenter can be achieved without requiring major $\mathrm{CO}_{2}$ sparging schemes which is favourable from an industrial processing perspective.
\end{abstract}

Keywords: Actinobacillus succinogenes; succinic acid; biofilm; $\mathrm{CO}_{2} ;$ metabolic flux distribution; mass transfer coefficient 


\section{Introduction}

Succinic acid has been identified as a top value-added [1] and bulk [2] chemical derived from biomass. This stems from both its presence in the tricarboxylic acid cycle which makes biological production plausible, as well as its potential to serve as a substitute and precursor for a number of petrochemicals, thereby augmenting the established market for SA [3]. In addition, SA can be employed as a reagent in the synthesis of bio-polymers such as polybutylene succinate and polyurethane [4]. Although bio-based SA production offers environmental advantages, its successful commercialisation is dependent on cost-competitive production compared to the traditional petrochemical route. To this end, a conversion process is required where a microbial host efficiently converts renewable feedstock into SA.

Various microbial strains have been investigated for SA production with the most promising being Actinobacillus succinogenes, Anaerobiospirillum succiniciproducens, Mannheimia succiniciproducens and recombinant strains of Escherichia coli [5]. Despite competitive performance achieved by all these organisms, A. succinogenes has received substantial interest due to its ability to naturally produce SA at appreciable titres, yields and productivities. Furthermore, A. succinogenes is tolerant to high acid concentrations [6], is able to convert a variety of carbohydrates to SA [7], and consumes $\mathrm{CO}_{2}$ in $\mathrm{SA}$ synthesis [8].

Given that $\mathrm{CO}_{2}$ is a co-substrate in the production of succinic acid, the effect of $\mathrm{CO}_{2}$ supply on SA production was studied in early publications on A. succinogenes [7,8]. Diffusion of dissolved $\mathrm{CO}_{2}$ across the cell membrane is the main transport mechanism for inorganic carbon supply to the cell, since $\mathrm{HCO}_{3}{ }^{-}$permeation through the lipid membrane is insignificant [9,10]. Accordingly, the transient concentration of dissolved $\mathrm{CO}_{2}$ in the broth $\left(\mathrm{C}_{\mathrm{CO}_{2}}\right)$ is the main driver for $\mathrm{CO}_{2}$ uptake by the cell. During fermentation, $\mathrm{C}_{\mathrm{CO}_{2}}$ will decrease if the rate of $\mathrm{CO}_{2}$ uptake by the cell exceeds the rate of $\mathrm{CO}_{2}$ supply to the fermentation broth. $\mathrm{CO}_{2}$ can 
either be supplied as a gas, requiring gas-liquid mass transfer, or in the form of a carbonate (i.e. $\mathrm{HCO}_{3}{ }^{-}, \mathrm{CO}_{3}{ }^{2-}$ ) in the liquid medium. Carbonate salts that are insoluble in water, such as $\mathrm{MgCO}_{3}$ and $\mathrm{CaCO}_{3}$, are often used as a source of $\mathrm{CO}_{2}$ in fermentation media $[8,10,11]$. For these cases, the dissolution rate of the solid will be the rate determining step since the carbonate-bicarbonate- $\mathrm{CO}_{2}$ equilibrium is rapidly established. Under typical fermentation conditions $\left(\mathrm{pH}=6.8, \mathrm{~T}=37^{\circ} \mathrm{C}\right.$ and $\mathrm{CO}_{2}$ atmosphere at 1 bar) the dissolved carbonate concentration is low, while bicarbonate and dissolved $\mathrm{CO}_{2}$ are present at approximately equal concentrations. The highest possible $\mathrm{C}_{\mathrm{CO}_{2}}$ value is determined by the $\mathrm{CO}_{2}$ partial pressure in the gas phase and is in the vicinity of $20 \mathrm{mM}$ for pure $\mathrm{CO}_{2}$ at atmospheric pressure [10-12].

It has been shown that the supply of $\mathrm{CO}_{2}$ influences $\mathrm{SA}$ productivity and catabolite distribution in A. succinogenes fermentations [8,10,11]. All these studies were performed in batch fermentations where the initial carbonate/bicarbonate concentrations and $\mathrm{CO}_{2}$ partial pressures were varied. Although these studies demonstrate that carbonate supply can have a detrimental effect on the fermentation outcome, the mechanism of the effect is unclear. In the majority of the experiments performed in these studies, only the final cumulative outcome of the batch fermentation is reported. However, the rate of formation of succinic acid varies appreciably within a batch run as there is an initial growth period followed by product inhibition towards the latter stages of the fermentation $[6,13]$. Accordingly, the uptake rate of $\mathrm{CO}_{2}$ remains variable throughout the fermentation likely causing fluctuations in $\mathrm{C}_{\mathrm{CO}_{2}}$. In one study [10], the $\mathrm{CO}_{2}$ supply is shown to be stoichiometrically limited by the initial concentration of carbonates (since carbonates are not replenished during the fermentation), thereby causing a $\mathrm{CO}_{2}$ shortage before the fermentation is complete. However, as mentioned above only the final, cumulative effect is reported. Variations in $\mathrm{CO}_{2}$ partial pressure can be used to estimate the value of $\mathrm{C}_{\mathrm{CO}_{2}}$ at saturation, although this does not guarantee that the 
broth is saturated because gas-liquid mass transfer can be rate controlling leading to $\mathrm{C}_{\mathrm{CO}_{2}}$ falling below the saturation value.

Proper design and scale-up of a succinic acid fermentation process cannot rely solely on the results of lab-scale systems. In addition, it is important that the supply of $\mathrm{CO}_{2}$ be linked to the transient value of $\mathrm{C}_{\mathrm{CO}_{2}}$ which drives the inorganic carbon supply. When opting for a gaseous $\mathrm{CO}_{2}$ supply, gas-liquid mass transfer should be carefully considered in order to achieve adequate $\mathrm{C}_{\mathrm{CO}_{2}}$ values without excessive (and expensive) sparging schemes. For carbonate supply, the influence of mixing on the dissolution rate of the solids should be considered in order to maintain the required $\mathrm{C}_{\mathrm{CO}_{2}}$ value in the medium. Both these routes require proper understanding and quantification of the effect of $\mathrm{C}_{\mathrm{CO}_{2}}$ on succinic acid yield and cell-based productivity. To date, studies have not addressed these crucial relationships but only hint at the importance of $\mathrm{CO}_{2}$ supply in SA fermentations.

In the current paper, the above mentioned shortcoming in A. succinogenes fermentation literature is addressed. Continuous fermentations were performed to enable steady-state analysis of the influence of $\mathrm{C}_{\mathrm{CO}_{2}}$ on succinic acid fermentations with A. succinogenes. Steady-state conditions ensure that $\mathrm{C}_{\mathrm{CO}_{2}}$ remains constant thereby allowing for a more accurate assessment of its influence on yield and cellular productivity. Gas-liquid mass transfer measurements were performed to calculate $\mathrm{C}_{\mathrm{CO}_{2}}$ at various steady-state conditions. The amount of immobilised biomass was controlled by operating at glucose-limiting conditions since continuous fermentations with A. succinogenes using rich growth media inevitably result in extensive biofilm formation. Mass balances were performed to ensure that all the major metabolites were accounted for. 


\section{Materials and methods}

\section{Organism and fermentation medium}

Cultures of Actinobacillus succinogenes 130Z (DSM 22257; ATCC 55618), acquired from the German Collection of Microorganisms and Cell Cultures (DSMZ), were maintained in $66 \% \mathrm{v} / \mathrm{v}$ glycerol solutions at $-40{ }^{\circ} \mathrm{C}$. Inoculum was prepared in sterilised tryptone soy broth at

$30 \mathrm{~g} \mathrm{~L}^{-1}$ and incubated at $37^{\circ} \mathrm{C}$ and $150 \mathrm{rpm}$ for 16 to $24 \mathrm{~h}$ in $30-\mathrm{mL}$ sealed vials. Prior to inoculation, inoculum was analyzed by HPLC to ensure culture purity and consistent metabolite distributions.

All chemicals were obtained from Merck KgaA unless indicated otherwise. The fermentation medium consisted of three parts: (1) a nutrient and salts mixture, (2) a carbohydrate solution and (3) a phosphate buffer. The nutrient and salts mixture was based on [14] and consisted of (in $\mathrm{g} \mathrm{L}^{-1}$ ): 16.0 yeast extract, $1.0 \mathrm{NaCl}, 0.2 \mathrm{MgCl}_{2} \cdot 6 \mathrm{H}_{2} \mathrm{O}, 0.2 \mathrm{CaCl}_{2} \cdot 2 \mathrm{H}_{2} \mathrm{O}$, sodium acetate (1.36), $\mathrm{Na}_{2} \mathrm{~S} \cdot 9 \mathrm{H}_{2} \mathrm{O}(0.16)$ and $0.5-1 \mathrm{~mL} \mathrm{~L}^{-1}$ Antifoam Y-30 (Sigma-Aldrich, Germany). The phosphate buffer comprised $1.6 \mathrm{~g} \mathrm{~L}^{-1} \mathrm{KH}_{2} \mathrm{PO}_{4}$ and $0.8 \mathrm{~g} \mathrm{~L}^{-1} \mathrm{~K}_{2} \mathrm{HPO}_{4}$. Glucose solutions were prepared at $25 \mathrm{~g} \mathrm{~L}^{-1}$.

\section{Continuous fermentations}

Three fermentations were performed in a custom, externally-recycled bioreactor, similar to that used in [15]. The volume was maintained at $358 \mathrm{~mL}$ by means of an overflow tube connected to an exit pump. $\mathrm{pH}$ was measured by a Ceragel CPS71D glass electrode (Endress+Hauser, Germany) connected to a Liquiline CM442 unit (Endress+Hauser, Germany) and controlled at $6.80 \pm 0.01$ by the addition of $10 \mathrm{~N} \mathrm{NaOH}$. Temperature was measured by the $\mathrm{pH}$ electrode and controlled at $37.0 \pm 0.1^{\circ} \mathrm{C}$ by means of a custom PID feedback controller coupled to a hotplate. A $20 \%$ v/v solution of Antifoam Y-30 (Sigma- 
Aldrich, Germany) was dosed onto the liquid headspace as needed. The average flow rates of $\mathrm{NaOH}$ and antifoam were determined in real-time over a 4-hr period and used to adjust feed concentrations due to dilution of the feed [16]. Furthermore, the time-profile of the average $\mathrm{NaOH}$ flow rate was used to estimate steady-state conditions. When the time-averaged dosing was relatively constant, showing only a $10 \%$ fluctuation around the average, it was assumed that the system had reached steady-state. $\mathrm{CO}_{2}$ gas (Afrox, South Africa) served as the inorganic carbon source and was fed directly into the recycle line at different flow rates (i.e. vvm). A vvm of 0.1 was sufficient to ensure $\mathrm{CO}_{2}$ saturation of the fermentation broth. $\mathrm{CO}_{2}$ flow rates were controlled using a Brooks 5850S mass flow controller (Brooks Instruments, Hungary). The reactor and liquid reservoirs (excluding $\mathrm{NaOH}$ ) were autoclaved together at $121{ }^{\circ} \mathrm{C}$ for $60 \mathrm{~min}$, with the three parts of the feed medium kept separate to prevent unwanted reactions.

A single wooden stick covered with strands of fiberglass was added to the centre of the reactor body in order to provide additional attachment area and support for biofilm.

\section{Analytical methods}

Samples were collected via the outlet pump. The sample container was placed in an ice bath to prevent further metabolic reactions taking place during sampling. The concentrations of glucose, ethanol and organic acids were determined using High-Performance Liquid Chromatography (HPLC). Analyses were performed using an Agilent 1260 Infinity HPLC (Agilent Technologies, USA), equipped with an RI detector and a $300 \mathrm{~mm}$ x $7.8 \mathrm{~mm}$ Aminex HPX-97 ion-exchange column (Bio-Rad Laboratories, USA). $\mathrm{An}_{2} \mathrm{SO}_{4}$ solution was used as the mobile phase at a flowrate of $0.6 \mathrm{~mL} \cdot \mathrm{min}^{-1}$ with a column temperature of $60{ }^{\circ} \mathrm{C}$. To overcome co-elution of chromatogram peaks, each sample was analysed with 5-mM and 20$\mathrm{mM}$ mobile phase solutions [15]. In the HPLC system used in the study, the retention time of 
acids decreases with increasing mobile phase acidity while the retention time of carbohydrates remains approximately constant, thereby allowing for separation of carbohydrate and acid peaks. Mass balances were performed by comparing the experimental amount of glucose consumed to the stoichiometric amount of glucose required to produce the measured metabolite concentrations [14].

\section{Control at substrate-limiting conditions}

At relatively high acid titres $\left(\mathrm{C}_{\mathrm{SA}}>10 \mathrm{~g} . \mathrm{L}^{-1}\right)$ growth of $A$. succinogenes is inhibited but does not terminate completely [17]. Under steady-state conditions of the reactor, it is assumed that limited growth occurs at all times, but cell accumulation is countered by biomass removal. On average these two rates should be similar in order to account for the observed steady-state behaviour (i.e. no net accumulation or removal of cells). However, if residual substrate is present in the broth, a secondary, long-term effect can occur where the biomass content in the fermenter (and the biomass in the outlet) gradually increases over extended periods while pseudo steady-state prevails. This effect needs to be prevented in order to maintain a constant amount of active biomass in the fermenter. To this end, continued cell growth was prevented by operating the reactor under substrate-limiting conditions (i.e. complete glucose conversion).

Overall cellular activity in the reactor is defined as the product of the concentration of active cells and specific cellular activity. Given a constant cellular concentration in the fermenter, if cellular activity decreases, substrate "breakthrough" can occur and the new availability of substrate could allow cellular activity or growth to increase. When substrate breakthrough occurs, the substrate loading needs to be decreased in order to maintain near-complete substrate conversion. To achieve this, the dilution rate can be decreased in proportion to the decrease in cellular activity. Thus, the amount of biomass in the fermenter is maintained and the decrease in dilution rate will directly relate to the decrease in activity. Moreover, 
regulating the glucose consumption by decreasing the dilution rate ensures that the total acid concentration remains relatively stable and the inhibitory effect of acids [6] remains constant. Therefore, the true influence of $\mathrm{CO}_{2}$ availability can be observed without interference from fluctuations in acid titre and cell growth.

\section{Dissolved $\mathrm{CO}_{2}$ calculations}

Mass transfer tests were performed in a liquid solution similar to the fermentation medium but excluded glucose and yeast extract. Mass transfer tests were conducted directly after the first fermentation (Run 1) in order to determine whether the presence of biomass influences mass transfer efficiency. The absence of glucose and yeast extract caused the remaining biomass in the reactor to be metabolically inactive.

In order to calculate the dissolved $\mathrm{CO}_{2}$ concentration in the fermentation broth, the following three processes need to be considered:

(A) Gas to liquid mass transfer

The volumetric $\mathrm{CO}_{2}$ mass transfer rate $\left(\mathrm{r}_{\mathrm{CO}_{2}}\right)$ from the gas bubble to the liquid fermentation broth (bulk liquid), with units of mol. $\mathrm{L}^{-1} \cdot \mathrm{h}^{-1}$, is given by Eq. (1).

$$
-\mathrm{r}_{\mathrm{CO}_{2}}=\mathrm{k}_{\mathrm{g}} \mathrm{a}_{\mathrm{g}}\left(\mathrm{C}_{\mathrm{CO}_{2}}^{*}-\mathrm{C}_{\mathrm{CO}_{2}}\right)
$$

In Eq. (1), $\mathrm{k}_{\mathrm{g}} \mathrm{a}_{\mathrm{g}}$ is the mass transfer coefficient $\left(\mathrm{h}^{-1}\right), \mathrm{C}_{\mathrm{CO}_{2}}^{*}$ is the saturated $\mathrm{CO}_{2}$ concentration at a specific $\mathrm{CO}_{2}$ partial pressure $\left(\mathrm{mol} . \mathrm{L}^{-1}\right)$ and $\mathrm{C}_{\mathrm{CO}_{2}}$ is the dissolved $\mathrm{CO}_{2}$ concentration in the bulk liquid (mol.L $\left.\mathrm{L}^{-1}\right)$.

(B) Gas-liquid equilibrium

Eq. (2) can be used to calculate the maximum dissolved $\mathrm{CO}_{2}$ concentration (mol. $\mathrm{L}^{-1}$ ) in the liquid at a known $\mathrm{CO}_{2}$ partial pressure $\left(\mathrm{P}^{*} \mathrm{CO}_{2}\right)$ in $\mathrm{kPa}$. 


$$
\mathrm{C}_{\mathrm{CO}_{2}}^{*}=\frac{\mathrm{P}_{\mathrm{CO}_{2}}^{*}}{\mathrm{H}}
$$

$\mathrm{H}$ is Henry's constant $\left(\mathrm{kPa} \cdot \mathrm{L} \cdot \mathrm{mol}^{-1}\right)$ for $\mathrm{CO}_{2}$ in a pure solvent. However, since the fermentation medium contains various salts and organic substances, the solubility of $\mathrm{CO}_{2}$ will be affected and therefore Henry's constant needs to be adjusted accordingly [10-12].

(C) $\mathrm{CO}_{2}$-carbonate equilibrium.

As $\mathrm{CO}_{2}$ dissolves in water, the equilibrium reactions given by Eq. (3) to (5) take place under steady-state conditions [10,11]. These reactions occur rapidly and equilibrium is established instantaneously.

$$
\begin{aligned}
& \mathrm{CO}_{2}+\mathrm{H}_{2} \mathrm{O} \leftrightarrow \mathrm{H}_{2} \mathrm{CO}_{3} \quad \mathrm{~K}_{1}=\frac{\mathrm{C}_{\mathrm{H}_{2} \mathrm{CO}_{3}}^{\mathrm{eq}}}{\mathrm{C}_{\mathrm{CO}_{2}}^{\mathrm{eq}}} \\
& \mathrm{H}_{2} \mathrm{CO}_{3} \leftrightarrow \mathrm{HCO}_{3}{ }^{-}+\mathrm{H}^{+} \quad \mathrm{K}_{2}=\frac{\mathrm{C}_{\mathrm{HCO}_{3}-}^{\mathrm{eq}} \mathrm{C}_{\mathrm{H}^{+}}^{\mathrm{eq}}}{\mathrm{C}_{\mathrm{H}_{2} \mathrm{CO}_{3}}^{\mathrm{eq}}}
\end{aligned}
$$

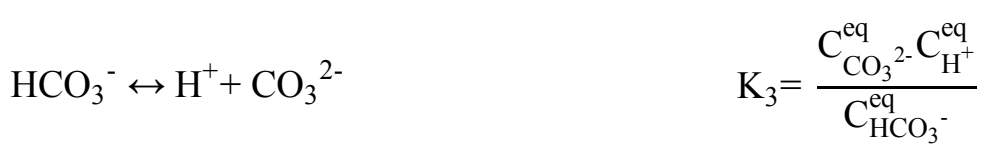

Carbonic acid $\left(\mathrm{H}_{2} \mathrm{CO}_{3}\right)$ is highly unstable in solution and is easily broken down. Therefore, Eq. (3) and (4) can be combined to form Eq. (6). Also, at a pH of 6.8, carbonate formation is insignificant and therefore Eq. (5) is not included in the $\mathrm{CO}_{2}$ transfer model.

$$
\mathrm{CO}_{2}+\mathrm{H}_{2} \mathrm{O} \leftrightarrow \mathrm{HCO}_{3}^{-}+\mathrm{H}^{+} \quad \mathrm{K}_{4}=\mathrm{K}_{1} \times \mathrm{K}_{2}=\frac{\mathrm{C}_{\mathrm{HCO}_{3}}^{\mathrm{eq}} \mathrm{C}_{\mathrm{H}^{+}}^{\mathrm{eq}}}{\mathrm{C}_{\mathrm{CO}_{2}}^{\mathrm{eq}}}
$$

Taking the effects discussed in A, B and C into account, a hydronium ion (Eq. (7)) and inorganic carbon (Eq.(8)) balance was performed for a continuous flow system with continuous $\mathrm{CO}_{2}$ sparing. No consumption of $\mathrm{CO}_{2}$ occurred since the biomass was inactive but $\mathrm{CO}_{2}$ was continuously removed from the system. 
Eq. (7) states that the amount of base added is equal to the sum of the hydronium ions formed in the equilibrium reaction (Eq. (6)) and the amount required to increase the $\mathrm{pH}$ of the feed from 6.4 to 6.8 (set point).

$$
\mathrm{Q}_{\mathrm{D}} \mathrm{C}_{\mathrm{OH}}=\left[\frac{\mathrm{K}_{4}}{\mathrm{C}_{\mathrm{H}^{+}}}\right] \mathrm{Q} \cdot \mathrm{C}_{\mathrm{CO}_{2}}+\mathrm{Q}_{\mathrm{feed}}\left(\mathrm{C}_{\mathrm{H}^{+}}^{\mathrm{feed}}-\mathrm{C}_{\mathrm{H}^{+}}\right)
$$

$\mathrm{Q}_{\mathrm{D}}$ is the sodium hydroxide flow rate $\left(\mathrm{L} \cdot \mathrm{h}^{-1}\right), \mathrm{C}_{\mathrm{OH}}$ is the concentration of the sodium hydroxide solution (mol. $\left.\mathrm{L}^{-1}\right), \mathrm{Q}$ is the total flow rate through the reactor $\left(\mathrm{L} \cdot \mathrm{h}^{-1}\right), \mathrm{Q}_{\text {feed }}$ is the feed flow rate into the vessel $\left(\mathrm{L} \cdot \mathrm{h}^{-1}\right), \mathrm{C}_{\mathrm{H}^{+}}^{\text {feed }}$ is the hydronium ion concentration at the feed $\mathrm{pH}$, $\mathrm{C}_{\mathrm{H}^{+}}$is the hydronium ion concentration at the operating $\mathrm{pH}\left(\mathrm{mol} . \mathrm{L}^{-1}\right)$ and $\mathrm{K}_{4}$ is the equilibrium constant in Eq. (6).

Eq. (8) states that the amount of $\mathrm{CO}_{2}$ transferred based on $\mathrm{H}^{+}$production from the equilibrium reaction (Eq.(6)) should be equal to the $\mathrm{CO}_{2}$ mass transfer rate.

$$
\left[1+\frac{\mathrm{K}_{4}}{\mathrm{C}_{\mathrm{H}^{+}}}\right] \mathrm{QC}_{\mathrm{CO}_{2}}=\mathrm{k}_{\mathrm{g}} \mathrm{a}_{\mathrm{g}}\left(\mathrm{C}_{\mathrm{CO}_{2}}^{*}-\mathrm{C}_{\mathrm{CO}_{2}}\right) \mathrm{V}
$$

The value for $\mathrm{K}_{4}$ in literature is reported as $\mathrm{K}_{4}=5.35 \times 10^{-7} \mathrm{~mol} \cdot \mathrm{L}^{-1}$ at $39^{\circ} \mathrm{C}$ [11]. However, there is a measure of uncertainty regarding the variation of $\mathrm{K}_{4}$ with temperature and feed composition. The first mass transfer experiments were performed to calculate a unique $\mathrm{K}_{4}$ value for the system used in the current study. These mass transfer tests were conducted at saturated conditions, i.e. low dilution rates $\left(\mathrm{D}=0.2 \mathrm{~h}^{-1}\right)$ and high $\mathrm{CO}_{2}$ flow rates $(\mathrm{vvm}=$ $15 \%$ ). During saturated conditions, a decrease in vvm will not significantly decrease the $\mathrm{NaOH}$ flow rate. With Q $\mathrm{D}_{\mathrm{D}}$ measured and all the other parameters of Eq. (7) known, a value for $\frac{\mathrm{K}_{4}}{\mathrm{C}_{\mathrm{H}^{+}}}$could be calculated. $\frac{\mathrm{K}_{4}}{\mathrm{C}_{\mathrm{H}^{+}}}$was found to be equal to 4.45 , giving a value of $7.053 \times 10^{-7}$ mol.L $\mathrm{L}^{-1}$ for $\mathrm{K}_{4}$. With $\mathrm{K}_{4}$ known, further mass transfer tests were carried out in which the $\mathrm{CO}_{2}$ vvm was varied to determine its effect on the mass transfer coefficient. The second set of 
mass transfer tests were performed at a high dilution rate $\left(1.0 \mathrm{~h}^{-1}\right)$ to ensure that $\mathrm{C}_{\mathrm{CO}_{2}}$ was sufficiently lower than the saturation point $\left(\mathrm{C}_{\mathrm{CO}_{2}}<0.7 \mathrm{C}_{\mathrm{CO}_{2}}^{*}\right)$. When $\mathrm{Q}_{\mathrm{D}}$ and $\mathrm{Q}$ at each vvm are known, Eq. (7) and Eq. (8) can be used to solve for $\mathrm{k}_{\mathrm{g}} \mathrm{a}_{\mathrm{g}}$ and $\mathrm{C}_{\mathrm{CO}_{2}}$.

During fermentation, the effect of $\mathrm{CO}_{2}$ consumption by the active biomass has to be taken into account. Adding a $\mathrm{CO}_{2}$ consumption term to Eq. (8) yields Eq. (9) which can be used to calculate the dissolved $\mathrm{CO}_{2}$ concentration when $\mathrm{kg}_{\mathrm{g}} \mathrm{a}_{\mathrm{g}}$ is known.

$$
\left.1+\frac{\mathrm{K}_{4}}{\mathrm{C}_{\mathrm{H}^{+}}}\right] \mathrm{QC}_{\mathrm{CO}_{2}}=\mathrm{k}_{\mathrm{g}} \mathrm{a}_{\mathrm{g}}\left(\mathrm{C}_{\mathrm{CO}_{2}}^{*}-\mathrm{C}_{\mathrm{CO}_{2}}\right) \mathrm{V}-\mathrm{r}_{\mathrm{CO}_{2}} \mathrm{~V}
$$

\section{Results and discussion}

$\mathrm{CO}_{2}$ mass transfer under continuous conditions

In investigating the influence of $\mathrm{CO}_{2}$ availability on succinic acid productivity and yield, it is more appropriate to use a basis that is not specific to reactor geometry but rather more generalised. To this end, the dissolved $\mathrm{CO}_{2}$ concentration $\left(\mathrm{C}_{\mathrm{CO}_{2}}\right)$ in the fermentation broth was chosen as the basis and not simply $\mathrm{CO}_{2}$ flow rate or mass transfer constants (i.e. vvm and $\mathrm{k}_{\mathrm{g}} \mathrm{a}_{\mathrm{g}}$ ). To indirectly determine $\mathrm{C}_{\mathrm{CO}_{2}}$, it is first necessary to determine the gas-based mass transfer coefficient, $\mathrm{k}_{\mathrm{g}} \mathrm{a}_{\mathrm{g}}$. As such, $\mathrm{k}_{\mathrm{g}} \mathrm{a}_{\mathrm{g}}$ was determined for each steady-state condition across a range of vvm values as described in Materials and methods. As can be seen in Fig. 1, $\mathrm{kga}_{\mathrm{g}}$ increases linearly with increasing vvm indicating that increased $\mathrm{CO}_{2}$ flow rates contribute directly to improved $\mathrm{CO}_{2}$ transfer into the fermentation broth and therefore increased availability of $\mathrm{CO}_{2}$ to the cell.

During the mass transfer experiments, the biomass present in the reactor dissolved and systematically washed out of the reactor after the fermentation medium was replaced with the 
Fig. 1. The gas-based $\mathrm{CO}_{2}$ mass transfer coefficient $\left(\mathrm{k}_{\mathrm{g}} \mathrm{a}_{\mathrm{g}}\right)$ as a function of $\mathrm{CO}_{2}$ gas flow rate (wm).

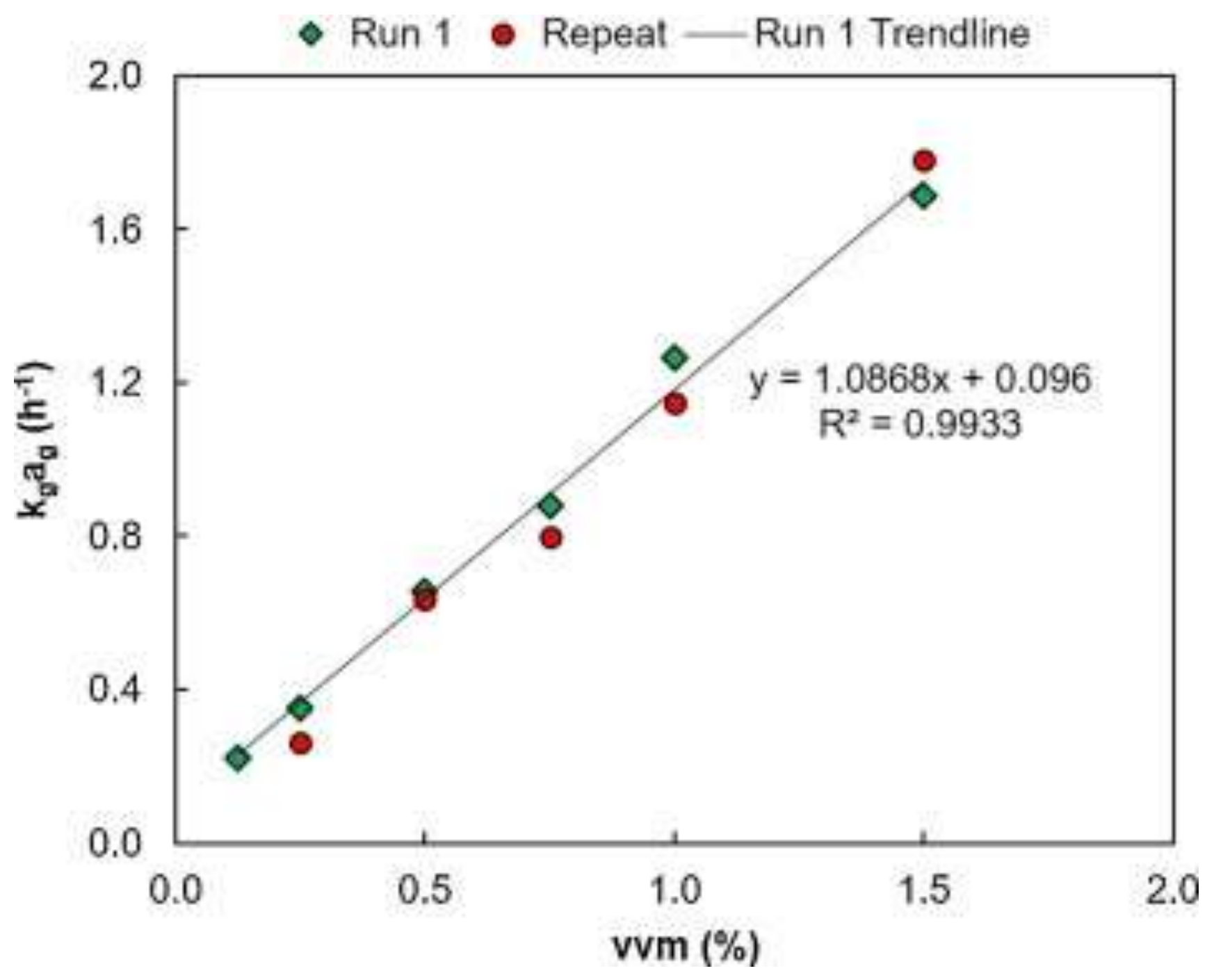


mass transfer solution. However, no differences between the initial and repeat tests were observed even though the last data point was obtained 26 days after the first. This demonstrates that the presence of biomass has a negligible influence on mass transfer efficiency and also that the procedure is repeatable. The linear relationship in Fig. 1 can be used to calculate $\mathrm{k}_{\mathrm{g}} \mathrm{a}_{\mathrm{g}}$ values at a specific vvm which, together with Eq. (9), can be used to determine the corresponding value of $\mathrm{C}_{\mathrm{CO}_{2}}$ and also the percentage $\mathrm{CO}_{2}$ saturation.

\section{Continuous fermentations}

The overall results of the three continuous fermentations are summarised in Table 1 in order of decreasing $\mathrm{C}_{\mathrm{CO}_{2}}$. Succinic acid concentrations were between 6.8 and 12.7 g.L.-1 with yields on glucose between 0.40 and $0.57 \mathrm{~g} \cdot \mathrm{g}^{-1}$ and productivities between 0.3 and $1.6 \mathrm{~g} \cdot \mathrm{L}^{-1} \cdot \mathrm{h}^{-1}$. On average, mass balance closures were $91 \%$ with a standard deviation of $3 \%$ which indicates that more glucose was consumed than was accounted for in the metabolites. This observation is similar to previous continuous fermentations with $A$. succinogenes biofilms where incomplete mass balance closures were observed on glucose [18], xylose [15] and corn stover hydrolysate [18]. In addition, the fermentation results are in agreement with previous studies on A. succinogenes using a complex fermentation medium containing yeast extract and no corn steep liquor $[13,19]$. Ethanol formation was found to increase with decreasing $\mathrm{C}_{\mathrm{CO}_{2}}$ levels which is in agreement with [8], where ethanol formation was observed at $\mathrm{CO}_{2}$ limiting conditions. Pyruvic acid formation was observed across various $\mathrm{C}_{\mathrm{CO}_{2}}$ levels but no distinct trend was found. Pyruvic acid production has been reported as a minor [7] and a considerable by-product [6] in glucose fermentations with A. succinogenes and as a more substantial byproduct in continuous xylose fermentations [15]. 
Table 1. Summary of the data for all three fermentations (runs).

\begin{tabular}{|c|c|c|c|c|c|c|c|c|c|c|c|c|c|c|}
\hline Run & $\begin{array}{c}\mathrm{CO}_{2} \mathrm{Vvm} \\
(\%)\end{array}$ & $\begin{array}{l}\mathrm{C}_{\mathrm{CO}_{2}} \\
(\mathrm{mM})\end{array}$ & $\begin{array}{c}\mathrm{CO}_{2} \\
\text { saturation } \\
(\%)\end{array}$ & $\begin{array}{c}\mathrm{D} \\
\left(\mathrm{h}^{-1}\right)\end{array}$ & $\begin{array}{c}\mathrm{C}_{\mathrm{SA}} \\
\left(\mathrm{g} \cdot \mathrm{L}^{-1}\right)\end{array}$ & $\begin{array}{c}\mathrm{C}_{\mathrm{AA}} \\
\left(\mathrm{g} \cdot \mathrm{L}^{-1}\right)\end{array}$ & $\begin{array}{c}\mathrm{C}_{\mathrm{FA}} \\
\left(\mathrm{g} \cdot \mathrm{L}^{-1}\right)\end{array}$ & $\begin{array}{l}\mathrm{C}_{\mathrm{EtOH}} \\
\left(\mathrm{g} . \mathrm{L}^{-1}\right)\end{array}$ & $\begin{array}{l}\mathrm{C}_{\mathrm{PYR}} \\
\left(\mathrm{g} \cdot \mathrm{L}^{-1}\right)\end{array}$ & $\begin{array}{l}\mathrm{C}_{\mathrm{GLCout}} \\
\left(\mathrm{g} \cdot \mathrm{L}^{-1}\right)\end{array}$ & $\begin{array}{l}\Delta \mathrm{C}_{\mathrm{GLC}} \\
\left(\mathrm{g} \cdot \mathrm{L}^{-1}\right)\end{array}$ & $\begin{array}{l}\mathrm{Y}_{\mathrm{GLCSA}} \\
\left(\mathrm{g} \cdot \mathrm{g}^{-1}\right)\end{array}$ & $\begin{array}{l}\mathrm{Y}_{\mathrm{AASA}} \\
\left(\mathrm{g} \cdot \mathrm{g}^{-1}\right)\end{array}$ & $\begin{array}{l}Y_{\text {AAFA }} \\
\left(\text { g. } g^{-1}\right)\end{array}$ \\
\hline \multirow{8}{*}{1} & 6.00 & 15.4 & 67 & 0.124 & 12.2 & 6.4 & 4.9 & 0.34 & $\overline{0}$ & 1.63 & 21.5 & 0.57 & 1.92 & 0.78 \\
\hline & 1.50 & 8.5 & 37 & 0.124 & 11.5 & 6.4 & 5.0 & 0.95 & 0 & 2.08 & 21.1 & 0.54 & 1.79 & 0.78 \\
\hline & 1.00 & 7.6 & 33 & 0.103 & 11.0 & 6.2 & 4.9 & 0.32 & 0 & 2.97 & 20.1 & 0.54 & 1.76 & 0.79 \\
\hline & 0.75 & 5.6 & 24 & 0.095 & 11.3 & 6.5 & 5.1 & 0.15 & 0.32 & 1.85 & 21.2 & 0.53 & 1.75 & 0.79 \\
\hline & 0.50 & 3.9 & 17 & 0.081 & 11.2 & 6.6 & 5.2 & 0.16 & 0.29 & 1.37 & 21.5 & 0.52 & 1.70 & 0.79 \\
\hline & 0.25 & 2.1 & 9 & 0.069 & 9.0 & 6.1 & 5.3 & 0.86 & 0.46 & 3.17 & 18.3 & 0.49 & 1.49 & 0.87 \\
\hline & 0.13 & 1.6 & 7 & 0.055 & 7.4 & 5.7 & 5.6 & 1.12 & 0.76 & 3.09 & 18.1 & 0.41 & 1.30 & 0.98 \\
\hline & 0.06 & 1.2 & 5 & 0.044 & 6.8 & 5.6 & 5.1 & 1.00 & 0.32 & 4.06 & 17.0 & 0.40 & 1.22 & 0.90 \\
\hline \multirow{5}{*}{2} & 8.00 & 17.6 & 77 & 0.124 & 11.3 & 7.0 & 5.4 & $\overline{0}$ & $\overline{0}$ & 0.313 & 20.8 & 0.54 & 1.60 & 0.77 \\
\hline & 8.00 & 17.5 & 77 & 0.129 & 12.7 & 7.7 & 5.9 & 0 & 0.24 & 0.28 & 23.1 & 0.55 & 1.66 & 0.77 \\
\hline & 6.00 & 17.0 & 75 & 0.131 & 10.9 & 6.7 & 5.3 & 0 & 0 & 0.45 & 19.6 & 0.56 & 1.62 & 0.78 \\
\hline & 4.00 & 16.0 & 70 & 0.131 & 10.5 & 6.7 & 5.2 & 0 & 0 & 0.46 & 19.6 & 0.54 & 1.59 & 0.78 \\
\hline & 2.50 & 14.4 & 63 & 0.128 & 11.2 & 7.1 & 5.8 & 0 & 0.40 & 0.54 & 23.1 & 0.49 & 1.57 & 0.82 \\
\hline \multirow{5}{*}{3} & 2.96 & 12.4 & $\overline{54}$ & 0.124 & 12.2 & 7.5 & 6.2 & 0.39 & 0.08 & 0.16 & 23.4 & 0.52 & 1.63 & 0.83 \\
\hline & 2.50 & 11.7 & 51 & 0.124 & 11.6 & 7.2 & 6.1 & 0.40 & 0 & 0.59 & 22.9 & 0.51 & 1.63 & 0.85 \\
\hline & 2.00 & 10.1 & 44 & 0.123 & 12.4 & 7.5 & 6.4 & 0.32 & 0 & 0.32 & 23.3 & 0.53 & 1.65 & 0.85 \\
\hline & 1.51 & 8.2 & 36 & 0.123 & 12.3 & 7.5 & 6.4 & 0.39 & 0.16 & 0.3 & 23.3 & 0.53 & 1.63 & 0.84 \\
\hline & 1.50 & 8.7 & 38 & 0.125 & 11.0 & 7.7 & 7.1 & 0.86 & 0.04 & 0.54 & 23.0 & 0.5 & 1.44 & 0.80 \\
\hline
\end{tabular}




\section{Productivity threshold}

The succinic acid productivity and rate of glucose uptake remained approximately constant with decreasing $\mathrm{C}_{\mathrm{CO}_{2}}$ down to a critical level, below which both parameters started to decrease (Fig. 2). The $\mathrm{C}_{\mathrm{CO}_{2}}$ level at which the decrease in succinic acid productivity and substrate uptake occurred can be considered an upper $\mathrm{C}_{\mathrm{CO}_{2}}$ threshold or productivity threshold $\left(\mathrm{C}_{\mathrm{CO}_{2}}^{\mathrm{P}}\right)$. In the current fermentation system, $\mathrm{C}_{\mathrm{CO}_{2}}^{\mathrm{P}}$ is equal to $8.4 \mathrm{mM} \mathrm{CO}$ which corresponds to approximately $36.8 \% \mathrm{CO}_{2}$ saturation. Since the biomass concentration is assumed to remain constant due to the imposed substrate limitation (through dilution rate adjustments), a decrease in productivity and substrate uptake suggests that either the cells are dying or the productivity per cell is decreasing, reflecting a decrease in the overall metabolic rate. It was observed that steady-states could be maintained for extended periods (greater than 48 hours) at low $\mathrm{CO}_{2}$ flow rates which hints that the decrease in productivity is related to a decrease in metabolic activity instead of cell death. This is plausible as one would expect a persistent decrease in productivity as cells died off, thereby preventing steady-state operation which was not the case in the current study.

The observation that SA productivity is independent of $\mathrm{C}_{\mathrm{CO}_{2}}$ above values of $8.4 \mathrm{mM}$ ties in with the results of [10] where variations in the $\mathrm{CO}_{2}$ partial pressure, hence $\mathrm{C}_{\mathrm{CO}_{2}}(5.1,10.1$, 15.2, and $20.2 \mathrm{mM}$ dissolved $\mathrm{C}_{\mathrm{CO}_{2}}$ ), was found to have no influence on final $\mathrm{SA}$ concentrations over constant batch times, although no decrease in productivity was observed at the $5.1 \mathrm{mM}$ condition either. However, [12] showed that SA yield and titre were enhanced when increasing the fermentation pressure from $101.3 \mathrm{kPa}$ to $140 \mathrm{kPa}$, due to the increased $\mathrm{CO}_{2}$ partial pressure and consequently higher $\mathrm{CO}_{2}$ saturation level in the broth. It is expected that $\mathrm{CO}_{2}$ availability to the cell should influence SA productivity since $\mathrm{CO}_{2}$ is essential for reductive TCA cycle flux (Fig. 3)and PEP carboxykinase activity in A. succinogenes. Furthermore, 
Fig. 2. The rate of glucose consumption and succinic acid production as a function of the dissolved $\mathrm{CO}_{2}$ concentration in the fermentation broth (also given as the fraction of $\mathrm{CO}_{2}$ saturation). The vertical arrow indicates the $\mathrm{C}_{\mathrm{CO} 2}$ level $(8.4 \mathrm{mM}$ or $36.8 \%$ saturated) at which the productivity and rate of glucose uptake starts to decrease (i.e. overall metabolic rate slows) and is considered the upper $\mathrm{CO}_{2}$ or productivity threshold $\left(\mathrm{C}_{\mathrm{CO}_{2}}^{\mathrm{P}}\right.$ ).

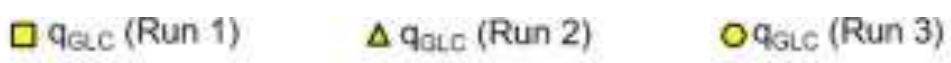

$$
\begin{aligned}
& \text { 口 } \mathrm{q}_{S A}\left(\text { Run 1) } \quad \Delta \mathrm{q}_{S A} \text { (Run 2) } \quad \mathrm{q}_{\mathrm{SA}}(\text { Run 3) }\right.
\end{aligned}
$$

\section{$\mathrm{CO}_{2}$ Saturation fraction}

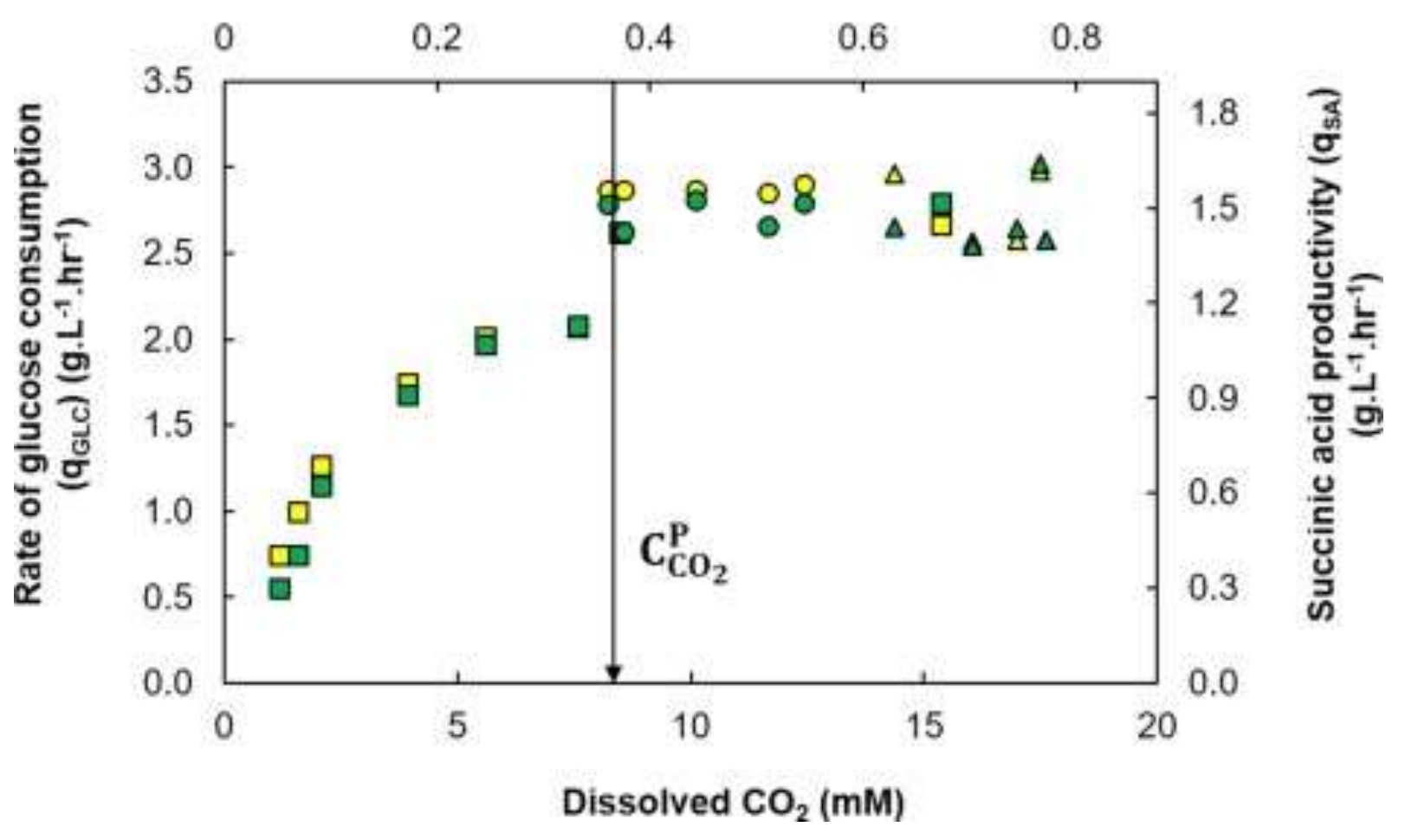


Fig. 3. Simplified central metabolic network of $A$. succinogenes showing all relevant pathways and metabolites. Adapted from [21] and [22]. AA = acetic acid; $\mathrm{AcCoA}=$ acetyl-CoA; $\mathrm{EtOH}=$ ethanol; FA = formic acid; G3P = glyceraldehyde-3-phosphate; Glc = glucose; $P E P=$ phosphoenolpyruvic acid; $P y r=$ pyruvic acid; Pyr $_{\mathrm{ex}}=$ excreted pyruvic acid; $\mathrm{SA}=$ succinic acid.




[9] showed that in fermentations of a mutant E. coli strain, the specific productivity and yield of SA improved substantially with increasing $\mathrm{CO}_{2}$ fraction (i.e. partial pressure) in the gas phase. In addition, an increase in carbon flux through the pentose phosphate pathway was observed to account for the increased demand for reduced cofactors.

\section{Yield threshold}

Similar to the trend of succinic acid productivity versus $\mathrm{C}_{\mathrm{CO}_{2}}$, the metabolite distributions remained constant with decreasing $\mathrm{C}_{\mathrm{CO}_{2}}$ down to a critical $\mathrm{C}_{\mathrm{CO}_{2}}$ level (Fig.4) of $3.9 \mathrm{mM} \mathrm{CO}$ (17.1\% of saturation). Below this level, the concentration of succinic acid started to decrease rapidly while acetic acid and formic acid concentrations remained fairly stable. A decrease in succinic acid concentration, while by-product concentrations remain constant or decrease to a smaller degree, is indicative of a shift in carbon flux away from the $\mathrm{C}_{4}$ pathway and towards the $\mathrm{C}_{3}$ pathway resulting in a decrease in the yield of succinic yield (fig. 3). Thereforeothevel at which this occurs can be considered a yield threshold and can be viewed as the lower $\mathrm{C}_{\mathrm{CO}_{2}}$ threshold $\left(\mathrm{C}_{\mathrm{CO}_{2}}^{\mathrm{Y}}\right)$ since it occurs at a lower $\mathrm{C}_{\mathrm{CO}_{2}}$ value to $\mathrm{C}_{\mathrm{CO}_{2}}^{\mathrm{P}}(8.4 \mathrm{mM})$.

The shift in carbon flux distribution occurs at the phosphoenolpyruvic acid (PEP) node which serves as the branch point between the $\mathrm{C}_{3}$ and $\mathrm{C}_{4}$ pathways. The shift can be further visualised in Fig. 5 where the fraction of total carbon flux in the $\mathrm{C}_{4}$ branch $\left(\mathrm{f}_{4}\right)$ decreases with decreasing $\mathrm{C}_{\mathrm{CO}_{2}}$. The fluxes through the $\mathrm{C}_{3}$ and $\mathrm{C}_{4}$ pathways are calculated based on the measured metabolite concentrations. Interestingly, the fraction of total carbon in the $\mathrm{C}_{4}$ branch only starts to decrease at very low $\mathrm{C}_{\mathrm{CO}_{2}}$ concentrations (17.1\% of $\mathrm{CO}_{2}$ saturation).

The flux shift under low $\mathrm{C}_{\mathrm{CO}_{2}}$ values suggests that a rate-limitation at the PEP node necessitates that flux be directed to the $\mathrm{C}_{3}$ pathway. Ethanol formation consumes two NADH molecules in A. succinogenes [20] and can therefore serve as a redox sink within the central 
Fig. 4. The metabolite concentrations as a function of the dissolved $\mathrm{CO}_{2}$ concentration in the broth. The distribution of metabolites remained constant down to a specific $\mathrm{C}_{\mathrm{CO} 2}$ level $\left(\mathrm{C}_{\mathrm{CO}_{2}}^{\mathrm{Y}}\right.$ ), below which SA production started to decrease.

$$
\begin{aligned}
& \bullet \mathrm{C}_{S A} \text { Run } 1 \quad \diamond \mathrm{C}_{S A} \text { Run } 2 \quad \diamond \mathrm{C}_{\text {SA Run } 3} \\
& \text { - } \mathrm{C}_{\mu A} \text { Run } 1 \quad \text { a } \mathrm{C}_{A M} \text { Run } 2 \text { a } \mathrm{C}_{\text {sa }} \text { Run 3 } \\
& \triangle C_{F A} \text { Run } 1 \quad \Delta C_{F A} \text { Run } 2 \quad \Delta C_{P A} \text { Run } 3
\end{aligned}
$$

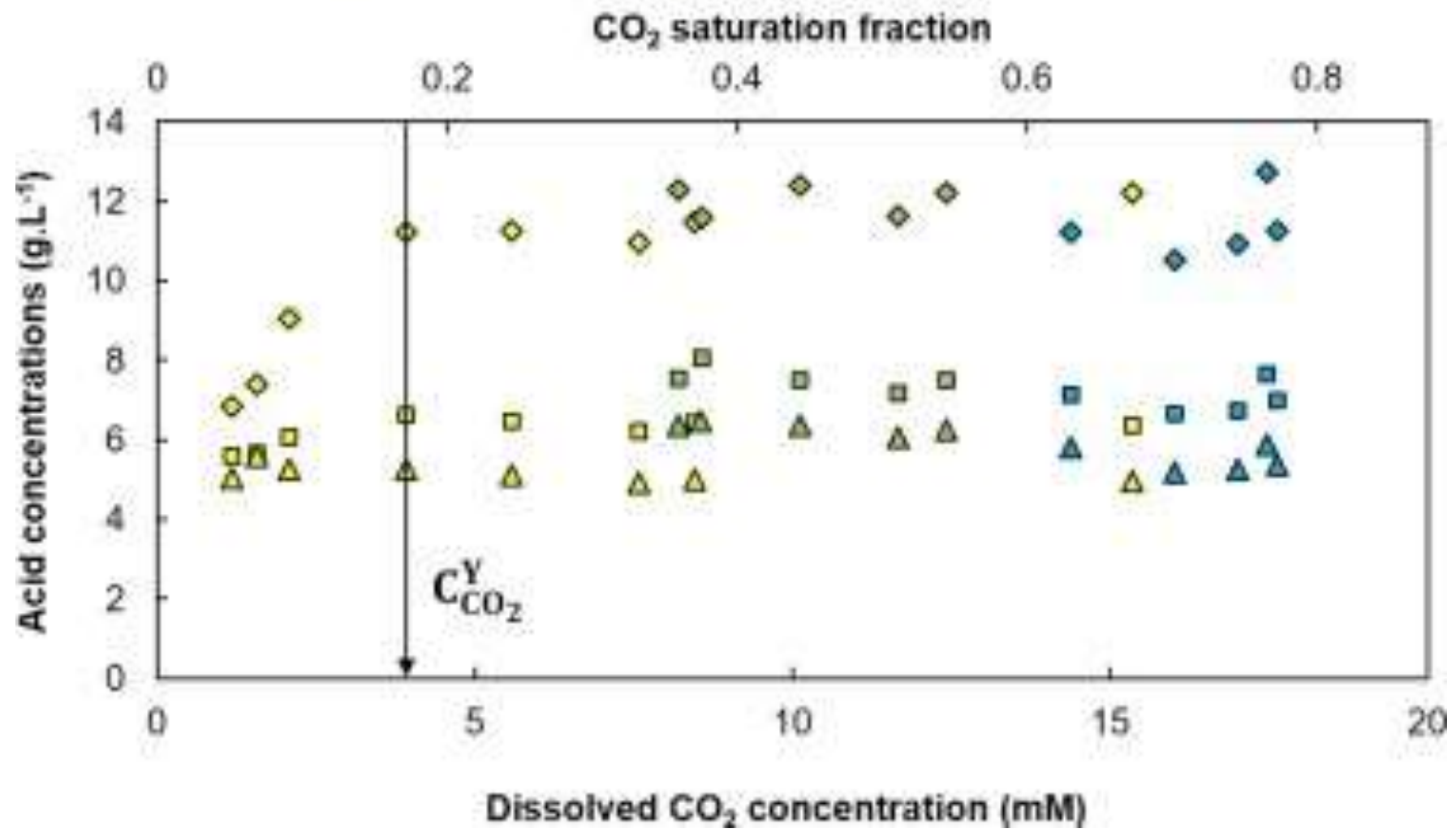


Fig. 5. The fraction of total carbon flux in the $\mathrm{C}_{4}$ branch $\left(\mathrm{f}_{4}\right)$ as a function of the dissolved $\mathrm{CO}_{2}$ concentration in the fermentation broth. The vertical arrow indicates the $\mathrm{C}_{\mathrm{CO} 2} \mathrm{CCO} 2$ level at which a shift in carbon flux distribution is observed and is considered the lower $\mathrm{CO}_{2}$ or yield threshold $\left(\mathrm{C}_{\mathrm{CO}}^{\mathrm{Y}}\right)$.

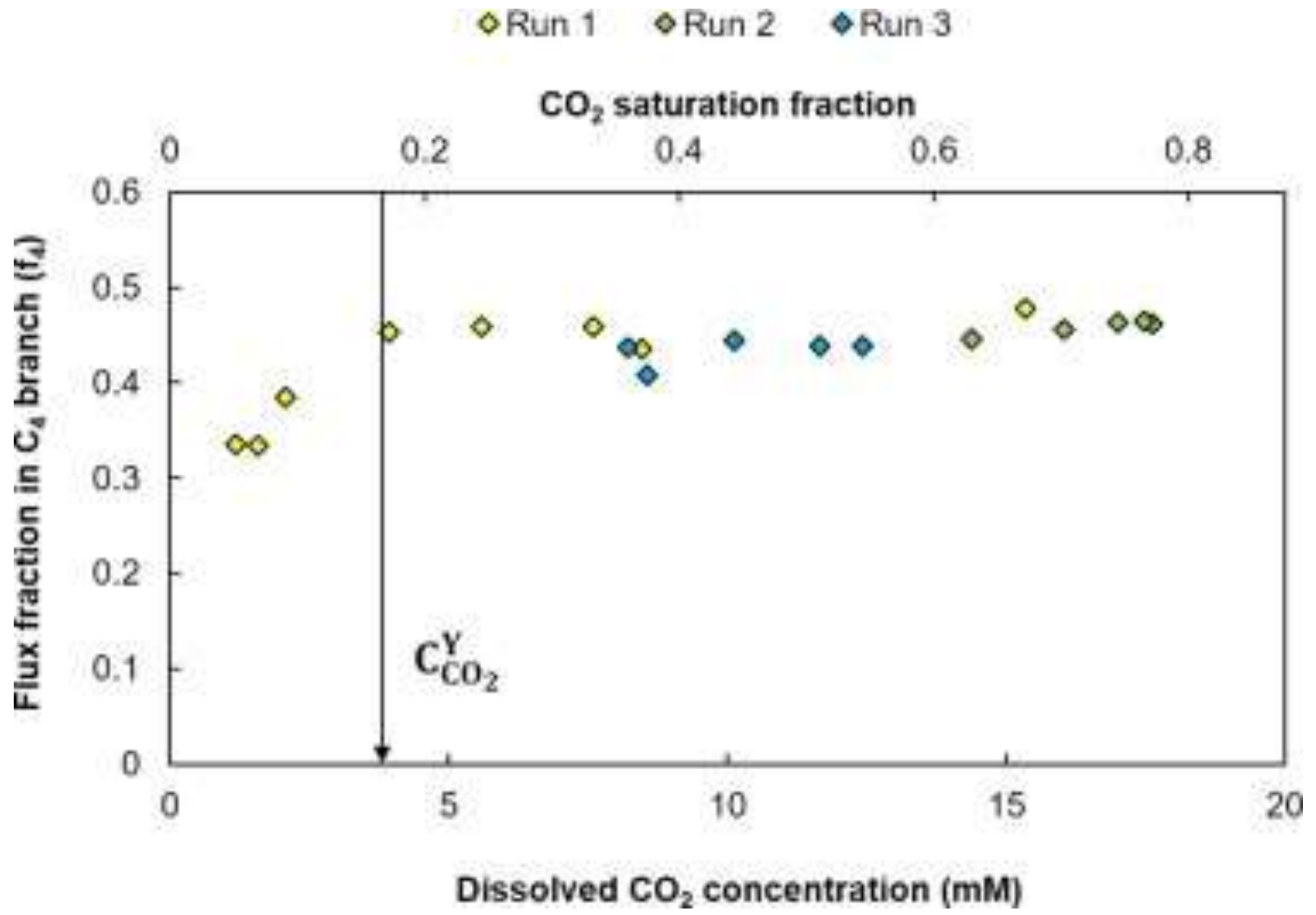


metabolism and as an alternative to the $\mathrm{C}_{4}$ pathway. If the PEP carboxykinase reaction is ratelimited due to insufficient $\mathrm{CO}_{2}$ availability, carbon flux to the $\mathrm{C}_{3}$ pathway at the PEP node could increase in order to balance redox via ethanol formation. While a flux shift occurred at the PEP node, flux at the pyruvate node proceeded solely via the pyruvate formate-lyase pathway as reflected by equimolar concentrations of formic acid and acetyl-CoA (Fig. 6). If pyruvate dehydrogenase or formate dehydrogenase activity were present, the ratio of acetylCoA to formic acid would increase proportionately since less formic acid would be formed per mole of acetyl-CoA formed. Furthermore, the formic acid-to-acetic acid ratio remained near the equimolar value of $0.77 \mathrm{~g} \mathrm{~g}^{-1}$, except during ethanol formation where the ratio increased because a fraction of acetyl-CoA was converted to ethanol instead of acetic acid.

The decrease in $\mathrm{C}_{\mathrm{CO}_{2}}$ in the broth directly affects the rate of $\mathrm{CO}_{2}$ uptake once $\mathrm{C}_{\mathrm{CO}_{2}}^{\mathrm{P}}$ is reached. Below $\mathrm{C}_{\mathrm{CO}_{2}}^{\mathrm{P}}$, the rate of PEP carboxylation (and succinic acid formation) decreases. The results suggest that glucose uptake in the region between the two thresholds (i.e. $\mathrm{C}_{\mathrm{CO}_{2}}^{\mathrm{Y}}<\mathrm{C}_{\mathrm{CO}_{2}}<\mathrm{C}_{\mathrm{CO}_{2}}^{\mathrm{P}}$ ) decreases in proportion to succinic acid flux, while the distribution of metabolites remains the same as when $\mathrm{C}_{\mathrm{CO}_{2}}>\mathrm{C}_{\mathrm{CO}_{2}}^{\mathrm{P}}$. This implies that the cellular rate of ATP generation also decreases. Therefore, less energy is available to the organism for maintenance processes yet the organism remains viable as seen by the prolonged operation under these conditions $\left(\mathrm{C}_{\mathrm{CO}_{2}}^{\mathrm{Y}}<\mathrm{C}_{\mathrm{CO}_{2}}<\mathrm{C}_{\mathrm{CO}_{2}}^{\mathrm{P}}\right)$.

A further decrease in $\mathrm{C}_{\mathrm{CO}_{2}}$ leads to the condition where $\mathrm{C}_{\mathrm{CO}_{2}}<\mathrm{C}_{\mathrm{CO}_{2}}^{\mathrm{Y}}$. Once the system enters this regime, a shift in metabolic flux distribution occurs where ethanol begins to form while carbon flux to succinic acid decreases. The low rate of $\mathrm{CO}_{2}$ uptake leads directly to the reduction in both succinic acid flux and PEP carboxylation. The question then arises why acetyl-CoA flux increases under this condition. It is evident that the redox balance 
Fig. 6. A parity plot of formic acid and acetyl-CoA. The solid diagonal line represents equimolar concentrations; data points lying on this line reflect exclusive pyruvate formate-lyase activity.
$\bullet$ Run 1
- Run 2
- Run 3
- Equimolar
$\cdots+10 \% \quad--\cdots 10 \%$

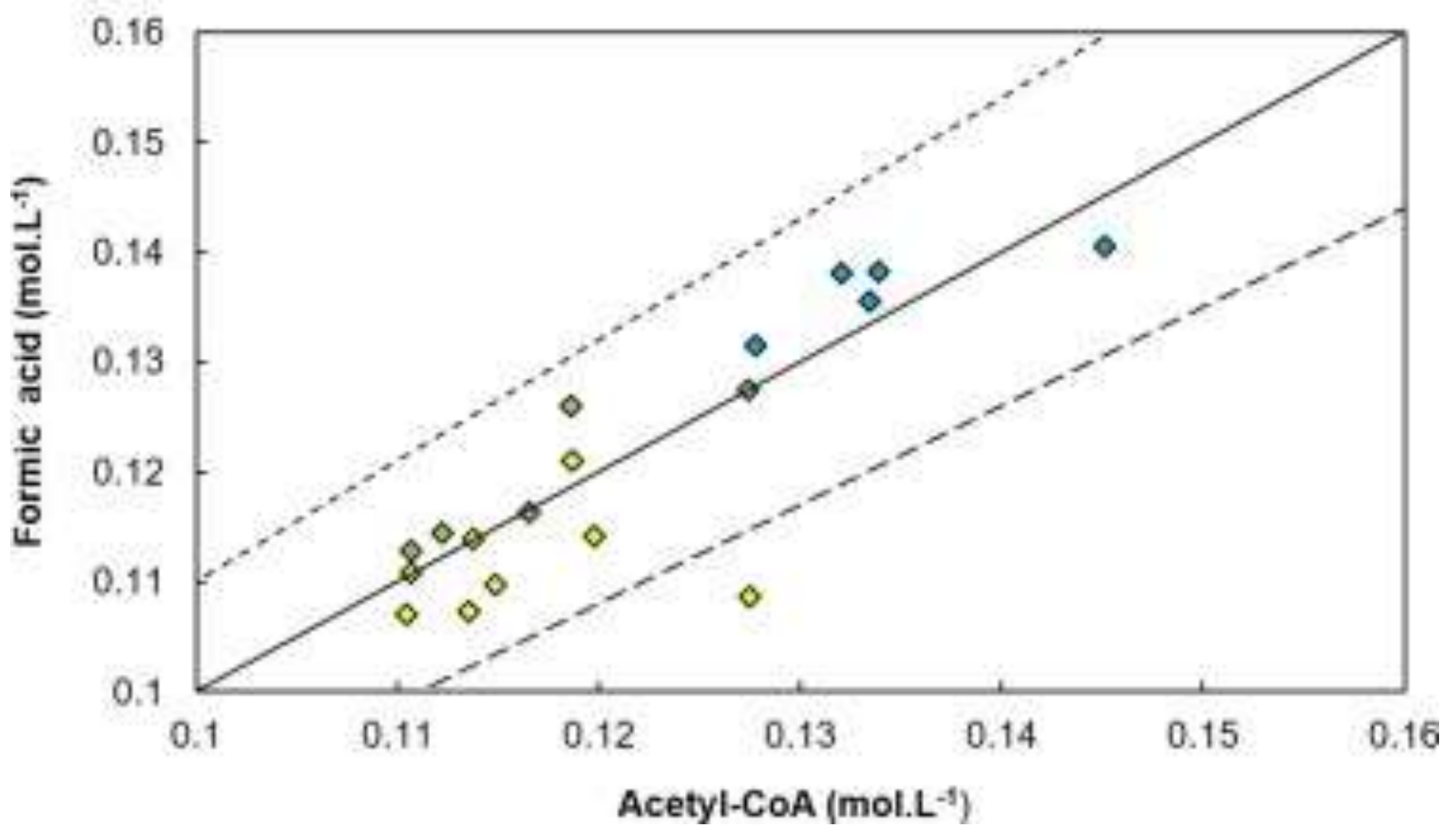


necessitates ethanol formation in order to consume excess NADH because succinic acid flux, hence flux through the reductive branch of the TCA cycle, decreases. However, the energy (i.e. ATP) implications of the shift are not obvious. Assuming that $2 / 3$ mole ATP is produced in converting fumaric acid to succinic acid [20], the yield of ATP on glucose consumed ( $\left.\mathrm{Y}_{\mathrm{SATP}}\right)$ can be calculated via a simple metabolic flux model where a redox balance is specified with no dehydrogenase activity (i.e. all pyruvate is converted by pyruvate formatelyase). The theoretical results are shown in Fig. 7 where both the ethanol ( $\left.\mathrm{Y}_{\mathrm{SE}}\right)$ and ATP ( $\left.\mathrm{Y}_{\mathrm{SATP}}\right)$ yield on glucose are given as a function of the fraction of PEP converted to succinic acid $\left(f_{S A}\right)$. It is clear that no gain in ATP is achieved with a decrease in $f_{S A}$. Therefore, the increase in acetyl-CoA flux does not provide any energy advantages and appears to be merely an overflow caused by the primary need to balance redox, where glucose uptake does not decrease in proportion to succinic acid flux. Consequently, the organism experiences a further decrease in the cellular rate of ATP generation. Despite this, the results suggest that cells are still viable under this condition as protracted steady-states were observed. 


\section{Conclusions}

$\mathrm{CO}_{2}$ is an important co-substrate in succinic acid production by A. succinogenes. To ensure efficient succinic acid production, the availability of $\mathrm{CO}_{2}$ to the cells needs to be maximised. In this study it is demonstrated that $\mathrm{CO}_{2}$ availability, as dissolved $\mathrm{CO}_{2}$ concentration $\left(\mathrm{C}_{\mathrm{CO}_{2}}\right)$ and percentage saturation of the fermentation broth, has two main thresholds when operating under continuous conditions. The first, or upper threshold, occurs at a $\mathrm{C}_{\mathrm{CO}_{2}}$ of $8.4 \mathrm{mM}$ (36.8\% saturation) and a gradual decrease in SA productivity and glucose uptake occurs as $\mathrm{C}_{\mathrm{CO}_{2}}$ is decreased below this threshold. As $\mathrm{C}_{\mathrm{CO}_{2}}$ is decreased further, a second, or lower, threshold occurs at $3.9 \mathrm{mM} \mathrm{C}_{\mathrm{CO}_{2}}$ (17\% saturation) below which SA productivity decreases further together with a shift in carbon flux away from the $\mathrm{C}_{4}$ pathway (succinic acid route) towards the $\mathrm{C}_{3}$ pathway (by-product route). In addition to the usual by-products (i.e. aceticand formic acid), ethanol formation was observed below the second threshold, likely as a means to balance redox. The $\mathrm{CO}_{2}$ thresholds occur at low values relative to full saturation, which is advantageous from an industrial processing perspective as it implies that the bulk liquid does not need to be maintained near $\mathrm{CO}_{2}$ saturation at all times. Instead, there can be some flexibility in the control of $\mathrm{CO}_{2}$ which may allow for reduced sparging and compression needs (i.e. lower $\mathrm{CO}_{2}$ pressure) thereby reducing operating expenses. Therefore, the results are useful for future design and optimisation of $\mathrm{CO}_{2}$ mass transfer systems in succinic acid fermentations with A. succinogenes. 


\section{Nomenclature}

\begin{tabular}{|c|c|c|}
\hline $\mathrm{C}_{\mathrm{AA}}$ & acetic acid concentration & g.. $\mathrm{L}^{-1}$ \\
\hline $\mathrm{C}_{\mathrm{CO}_{2}}^{\mathrm{eq}}$ & $\mathrm{CO}_{2}$ concentration at equilibrium & $\operatorname{mol} . \mathrm{L}^{-1}$ \\
\hline $\mathrm{C}_{\mathrm{CO}_{2}}$ & dissolved $\mathrm{CO}_{2}$ concentration in broth & $\operatorname{mol} . \mathrm{L}^{-1}$ \\
\hline $\mathrm{C}_{\mathrm{CO}_{2}}^{*}$ & dissolved $\mathrm{CO}_{2}$ concentration at saturation & $\operatorname{mol.L} \mathrm{L}^{-1}$ \\
\hline $\mathrm{C}_{\mathrm{CO}_{2}}^{\mathrm{P}}$ & dissolved $\mathrm{CO}_{2}$ concentration at productivity threshold & $\operatorname{mmol} . \mathrm{L}^{-1}$ \\
\hline $\mathrm{C}_{\mathrm{CO}_{2}}^{\mathrm{Y}}$ & dissolved $\mathrm{CO}_{2}$ concentration at yield threshold & $\operatorname{mmol} . \mathrm{L}^{-1}$ \\
\hline $\mathrm{C}_{\mathrm{H}^{+}}^{\mathrm{feed}}$ & proton concentration in feed & mol.L $\mathrm{L}^{-1}$ \\
\hline $\mathrm{C}_{\mathrm{H}^{+}}$ & proton concentration in broth & $\operatorname{mol} . L^{-1}$ \\
\hline $\mathrm{C}_{\mathrm{H}^{+}}^{\mathrm{eq}}$ & hydronium ion concentration at equilibrium & $\operatorname{mol} . L^{-1}$ \\
\hline $\mathrm{C}_{\mathrm{H}_{2} \mathrm{CO}_{3}}^{\mathrm{eq}}$ & $\mathrm{H}_{2} \mathrm{CO}_{3}$ concentration at equilibrium & $\operatorname{mol} . L^{-1}$ \\
\hline $\mathrm{C}_{\mathrm{HCO}_{3}^{-}}^{\mathrm{eq}}$ & $\mathrm{HCO}_{3}{ }^{-}$concentration at equilibrium & mol.L $\mathrm{L}^{-1}$ \\
\hline $\mathrm{C}_{\mathrm{OH}}$ & sodium hydroxide concentration & mol.L $\mathrm{L}^{-1}$ \\
\hline $\mathrm{C}_{\mathrm{SA}}$ & succinic acid concentration & g.. $\mathrm{L}^{-1}$ \\
\hline $\mathrm{f}_{4}$ & fraction of total carbon flux in the $\mathrm{C}_{4}$ pathway & \\
\hline $\mathrm{f}_{\mathrm{SA}}$ & fraction of phosphoenolpyruvic acid converted to succi & acid \\
\hline $\mathrm{H}_{0}$ & Henry's constant in pure solvent & $\mathrm{kPa} \cdot \mathrm{L} \cdot \mathrm{mol}^{-1}$ \\
\hline $\mathrm{K}_{1}$ & equilibrium constant - carbonic acid formation & $\operatorname{mol} . \mathrm{L}^{-1}$ \\
\hline $\mathrm{K}_{2}$ & equilibrium constant - bicarbonate formation & $\operatorname{mol} . L^{-1}$ \\
\hline $\mathrm{K}_{3}$ & equilibrium constant - carbonate formation & $\operatorname{mol.L} \mathrm{L}^{-1}$ \\
\hline $\mathrm{K}_{4}$ & equilibrium constant & $\operatorname{mol} . \mathrm{L}^{-1}$ \\
\hline $\mathrm{k}_{\mathrm{g}} \mathrm{a}_{\mathrm{g}}$ & gas-based mass transfer coefficient & $\mathrm{h}^{-1}$ \\
\hline $\mathrm{P}_{\mathrm{CO}_{2}}^{*}$ & $\mathrm{CO}_{2}$ partial pressure & $\mathrm{kPa}$ \\
\hline Q & overall volumetric flow rate & $\mathrm{mL} \cdot \min ^{-1}$ \\
\hline $\mathrm{Q}_{\mathrm{D}}$ & sodium hydroxide flow rate & $\mathrm{mL} \cdot \mathrm{min}^{-1}$ \\
\hline $\mathrm{Q}_{\text {feed }}$ & feed flow rate & $\mathrm{mL} \cdot \min ^{-1}$ \\
\hline $\mathrm{q}_{\mathrm{Glc}}$ & glucose consumption rate & g. $\mathrm{L}^{-1} \mathrm{~h}^{-1}$ \\
\hline $\mathrm{q}_{\mathrm{SA}}$ & succinic acid productivity & g. $L^{-1} h^{-1}$ \\
\hline $\mathrm{r}_{\mathrm{CO}_{2}}$ & rate of $\mathrm{CO}_{2}$ transfer & $\operatorname{mol} . L^{-1} \cdot h^{-1}$ \\
\hline $\mathrm{V}$ & reactor volume & $\mathrm{mL}$ \\
\hline
\end{tabular}




\section{References}

[1] J.J. Bozell, G.R. Petersen, Technology development for the production of biobased products from biorefinery carbohydrates - the US Department of Energy's “Top 10" revisited, Green Chem. 12 (2010) 539. doi:10.1039/b922014c.

[2] M. Patel, M. Cranck, V. Dornburg, B. Hermann, L. Roes, B. Husing, The BREW project - Medium and Long-term Opportunities and Risks of the Biotechnological Production of Bulk Chemicals from Renewable Resources, 2006.

[3] H. Song, S.Y. Lee, Production of succinic acid by bacterial fermentation, Enzyme Microb. Technol. 39 (2006) 352-361. doi:10.1016/j.enzmictec.2005.11.043.

[4] I. Bechthold, K. Bretz, S. Kabasci, R. Kopitzky, A. Springer, Succinic Acid: A new platform chemical for biobased polymers from renewable resources, Chem. Eng. Technol. 31 (2008) 647-654. doi:10.1002/ceat.200800063.

[5] J.J. Beauprez, M. De Mey, W.K. Soetaert, Microbial succinic acid production: Natural versus metabolic engineered producers, Process Biochem. 45 (2010) 1103-1114. doi:10.1016/j.procbio.2010.03.035.

[6] S.K.C. Lin, C. Du, A. Koutinas, R. Wang, C. Webb, Substrate and product inhibition kinetics in succinic acid production by Actinobacillus succinogenes, Biochem. Eng. J. 41 (2008) 128-135. doi:10.1016/j.bej.2008.03.013.

[7] M. Guettler, D. Rumler, M. Jain, Actinobacillus succinogenes sp. nov., a novel succinic-acid-producing strain from the bovine rumen, Int. J. Syst. Bacteriol. 49 (1999) 207-216. http://ijs.sgmjournals.org/content/49/1/207.short (accessed December 9, 2012).

[8] M.J. Van der Werf, M. V Guettler, M.K. Jain, J.G. Zeikus, Environmental and 
physiological factors affecting the succinate product ratio during carbohydrate fermentation by Actinobacillus sp. 130Z, Arch. Microbiol. 167 (1997) 332-42. http://www.ncbi.nlm.nih.gov/pubmed/9148774.

[9] S. Lu, M. a Eiteman, E. Altman, Effect of $\mathrm{CO}_{2}$ on succinate production in dual-phase Escherichia coli fermentations., J. Biotechnol. $143 \quad$ (2009) 213-23. doi:10.1016/j.jbiotec.2009.07.012.

[10] W. Zou, L.-W. Zhu, H.-M. Li, Y.-J. Tang, Significance of $\mathrm{CO}_{2}$ donor on the production of succinic acid by Actinobacillus succinogenes ATCC 55618, Microb. Cell Fact. 10 (2011) 87. doi:10.1186/1475-2859-10-87.

[11] Y. Xi, K. Chen, J. Li, X. Fang, X. Zheng, S. Sui, et al., Optimization of culture conditions in $\mathrm{CO} 2$ fixation for succinic acid production using Actinobacillus succinogenes, J. Ind. Microbiol. Biotechnol. 38 (2011) 1605-12. doi:10.1007/s10295011-0952-5.

[12] I.B. Gunnarsson, M. Alvarado-Morales, I. Angelidaki, Utilization of $\mathrm{CO}_{2}$ fixating bacterium Actinobacillus succinogenes $130 \mathrm{Z}$ for simultaneous biogas upgrading and biosuccinic acid production, Environ. Sci. Technol. 48 (2014) 12464-8. doi:10.1021/es504000h.

[13] R.I. Corona-González, A. Bories, V. González-Álvarez, C. Pelayo-Ortiz, Kinetic study of succinic acid production by Actinobacillus succinogenes ZT-130, Process Biochem. 43 (2008) 1047-1053. doi:10.1016/j.procbio.2008.05.011.

[14] M.F.A. Bradfield, W. Nicol, Continuous succinic acid production by Actinobacillus succinogenes in a biofilm reactor: Steady-state metabolic flux variation, Biochem. Eng. J. 85 (2014) 1-7. doi:10.1016/j.bej.2014.01.009. 
[15] M.F.A. Bradfield, W. Nicol, Continuous succinic acid production from xylose by Actinobacillus succinogenes, Bioprocess Biosyst. Eng. 39 (2016) 233-244. doi:10.1007/s00449-015-1507-3.

[16] C. Van Heerden, W. Nicol, Continuous succinic acid fermentation by Actinobacillus succinogenes, Biochem. Eng. J. 73 (2013) 5-11. doi:10.1016/j.bej.2013.01.015.

[17] H.G. Brink, W. Nicol, Succinic acid production with Actinobacillus succinogenes: rate and yield analysis of chemostat and biofilm cultures., Microb. Cell Fact. 13 (2014) 111. doi:10.1186/s12934-014-0111-6.

[18] M.F.A. Bradfield, A. Mohagheghi, D. Salvachúa, H. Smith, B.A. Black, N. Dowe, et al., Continuous succinic acid production by Actinobacillus succinogenes on xyloseenriched hydrolysate, Biotechnol. Biofuels. 8 (2015) 181. doi:10.1186/s13068-0150363-3.

[19] R.I. Corona-Gonzalez, A. Bories, V. González-Alvarez, R. Snell-Castro, G. TorizGonzález, C. Pelayo-Ortiz, Succinic acid production with Actinobacillus succinogenes ZT-130 in the presence of succinic acid, Curr. Microbiol. 60 (2010) 71-7. doi:10.1007/s00284-009-9504-x.

[20] J.B. McKinlay, M. Laivenieks, B.D. Schindler, A. a McKinlay, S. Siddaramappa, J.F. Challacombe, et al., A genomic perspective on the potential of Actinobacillus succinogenes for industrial succinate production., BMC Genomics. 11 (2010) 680. doi:10.1186/1471-2164-11-680. 